\title{
Acetylcholinesterase secreted by Anisakis simplex larvae (Nematoda: Anisakidae) parasitizing herring, Clupea harengus: an inverse relationship of enzyme activity in the host-parasite system
}

\author{
Magdalena Podolska $\cdot$ Katarzyna Nadolna
}

Received: 19 February 2014 / Accepted: 24 March 2014 / Published online: 5 April 2014

(C) The Author(s) 2014. This article is published with open access at Springerlink.com

\begin{abstract}
Acetylcholinesterase (AChE) is a key enzyme involved in nerve impulse transmission in both vertebrates and invertebrates. In addition to neuromuscular AChE, many parasitic nematodes synthesize AChE in secretory glands and release the enzyme into their external environment. In this study, we evaluate the activities of both somatic and secreted AChE from larvae (L3) of the parasitic nematode Anisakis simplex, and compare these to the AChE activity in its host, herring, Clupea harengus. A. simplex larvae were obtained from a herring sampled in three areas of the southern Baltic. Enzyme kinetics were determined for excretory/secretory (E/S) products and somatic extracts of larvae as well as for herring muscle tissue. The results reveal that mean $\mathrm{AChE}$ activity is approximately fourfold higher in E/S products and eightfold higher in somatic extracts of post-secretory A. simplex larvae than in host muscle tissue. The level of $\mathrm{AChE}$ activity in nematodes is inversely related to the enzyme activity in their hosts, i.e. reduced AChE activity in herring was accompanied by increased enzyme activity in its parasites. The physiological function of AChE secreted by parasitic nematodes has been widely discussed in the literature, and numerous roles for this form of enzyme have been suggested. The results of our investigation indicate that $\mathrm{AChE}$ secretion by $A$. simplex larvae may constitute an adaptive mechanism that promotes survival under adverse environmental conditions. Larvae probably increase secretion of $\mathrm{AChE}$ in response to a direct and/or indirect effect of neurotoxic compounds. This is the first report of such a phenomenon in A. simplex.
\end{abstract}

\footnotetext{
M. Podolska $(\bowtie) \cdot K$. Nadolna

National Marine Fisheries Research Institute, Kollataja 1,

81-332 Gdynia, Poland

e-mail: bilbo@mir.gdynia.pl
}

Keywords Anisakis simplex · Herring ·

Acetylcholinesterase $\cdot$ Host-parasite system

\section{Introduction}

Cholinesterases are polymorphic enzymes involved in nerve impulse transmission in both vertebrates and invertebrates. Two major classes of cholinesterase exist in vertebrates: acetylcholinesterase (AChE), whose preferred substrate is acetylcholine (ACh), and the closely related butyrylcholinesterase, which has a high affinity for butyrylcholine as a substrate (Massoulie 2002). In all invertebrates studied so far (i.e. nematodes and arthropods), the only cholinesterases found are of the AChE class (Toutant 1989; Combes et al. 2000; Kang et al. 2011a, b). Two different AChE genes have been defined in various arthropod species (Baxter and Barker 2002; Weill et al. 2002, 2003; Lee et al. 2006). Multiple forms of enzyme were identified in plant-parasitic nematodes: for example, three AChEs were defined in Heterodera glycines (Chang and Opperman 1992) and five in Meloidogyne incognita and Meloidogyne arenaria (Chang and Opperman 1991). Kang et al. (2011a) found three AChEs in pinewood nematode Bursaphelenchus xylophilus, each with a distinct physiological function.

Invertebrate $\mathrm{AChE}$ exists in both membrane-bound (amphiphilic) and soluble (hydrophilic) forms (Hyne and Maher 2003). Thus, membrane-bound (neuromuscular) AChEs have been characterized in parasitic nematodes such as Trichinella spiralis (DeVos and Dick 1992), Parascaris equorum (Talesa et al. 1997), Nippostrongylus brasiliensis (Hussein et al. 1999a) and Dictyocaulus viviparus (Lazari et al. 2004; Pezzementi et al. 2012). In the insect parasite Steinernema carpocapsae, two types of amphiphilic AChE were described by Arpagaus et al. (1992). 
In addition to producing membrane-bound $\mathrm{AChE}$, several species of parasitic nematodes secrete a soluble form of this enzyme into their external environment. This was first documented by analysis of secretory products obtained from cultures of N. brasiliensis (Sanderson 1972). Later studies on this nematode revealed three secreted forms of AChE (Grigg et al. 1997; Hussein et al. 1999b). Secretory AChE was also demonstrated in Trichostrongylus colubriformis (Griffiths and Pritchard 1994) and Necator americanus (Pritchard et al. 1994). Two variants of secretory AChEs were identified in Setaria cervi microfilariae (Sharma et al. 1998) and the lungworm D. viviparus (Lazari et al. 2003; Pezzementi et al. 2012). Recent results obtained by Podolska et al. (2012) suggest that Anisakis simplex larvae contain two AChE forms, which are proposed to be neuromuscular and secreted variants.

$\mathrm{AChE}$ is the biochemical target of organophosphates (OPs) and carbamate pesticides (CBs), irreversible or quasiirreversible inhibitors of the enzyme, that are widely used to control insects. In addition to pesticides, other neurotoxic agents possess anti-AChE properties, including heavy metals, some types of chemical weapons and anthelmintic drugs, as well as cyanobacterial toxins. The application of pesticides can have unfortunate consequences, which are not limited to rural areas. Pesticides run off from fields to rivers, lakes and seas, reaching areas far from their point of use. For example, one side effect of the application of anticholinergic insecticides is the negative impact on the aquatic environment, exemplified by both acute and chronic toxicity in living organisms.

It is difficult to directly link $\mathrm{AChE}$ inhibition to $\mathrm{OP}$ or $\mathrm{CB}$ exposure, because these compounds have a short half-life. Most OPs degrade rapidly in the environment, and their concentrations in environmental samples may fall below detectable levels within hours to days (Fulton and Key 2001). The half-life of carbofurans is about 30-120 days, depending on the pesticide and on the $\mathrm{pH}$ and temperature of the aqueous environment (Morales et al. 2012).

$\mathrm{AChE}$ activity measurement is widely used in biomonitoring to assess neurotoxic effects in various marine species, including fish (Dembele et al. 1999; Niemi et al. 2002; Napierska and Podolska 2005; Barsiene et al. 2006). AChE is a very sensitive biomarker, and detection of inhibitory effects is possible even after exposure to low concentrations of insecticides (Habig et al. 1986). Although neurotoxic agents usually inhibit AChE activity in many species of fish, the opposite response may be observed in their parasites. Studies carried out by Podolska and Napierska (2006) revealed that $\mathrm{AChE}$ inhibition in muscle tissue of herring Clupea harengus caught in polluted areas was accompanied by very high enzyme activity in tissue extracts of herring parasites, A. simplex larvae. Further investigation (Podolska et al. 2008) indicated that AChE activity may increase in
A. simplex larvae after experimental exposure to carbofuran. The most recent results show that AChE secreted by A. simplex larvae is characterized by a high level of activity (Podolska et al. 2012).

The objective of the study was to test the hypothesis that AChE secreted by $A$. simplex larvae from herring determines the relationship observed between host and parasite $\mathrm{AChE}$ activity in areas of the Baltic polluted with neurotoxic compounds.

\section{Materials and methods}

\section{Sample collection}

Samples of herring (C. harengus) were collected during the spring spawning period (from April to May 2011) in the coastal waters of the southern Baltic Sea in three locations: (1) Vistula Lagoon, (2) Gulf of Gdansk, and (3) the middle coast (Fig. 1). Standard measurements were performed on each fish. The presence of $A$. simplex larvae in the body cavity of each fish was recorded by macroscopic examination, and only fish containing parasites (total number 107) were chosen for further analyses. These individuals were placed with their anterior part facing leftwards, and a sample of muscle tissue was dissected from the posterior part of the fish, close to the tail fin. Samples of herring muscle were frozen immediately at $-80{ }^{\circ} \mathrm{C}$ for further biochemical analyses. Live $A$. simplex larvae (L3) were collected, and the following procedure was used to acquire the excretory/secretory $(\mathrm{E} / \mathrm{S})$ products of the larvae: live nematodes (8-10 individuals per sample) were washed in physiological $\mathrm{NaCl}$ solution and maintained for $24 \mathrm{~h}$ at $4{ }^{\circ} \mathrm{C}$ in Eppendorf tubes containing $100 \mu \mathrm{l}$ of physiological $\mathrm{NaCl}$ solution. The larvae were then removed from the tubes, washed and placed in new tubes. The E/S products and post-secretory larvae were frozen at $-80{ }^{\circ} \mathrm{C}$ for further analyses.

Preparation of tissue homogenates

Herring muscle tissue samples and A. simplex post-secretory larvae (pooled samples of 8-10 individuals) were homogenized using a mechanical blender. The AChE extraction was performed using 250-300 mg of herring muscle tissue (or 20$30 \mathrm{mg}$ of larval tissue) in $0.02 \mathrm{M}$ phosphate buffer ( $\mathrm{pH} 7.0$ ) containing $0.1 \%$ Triton X-100. The herring tissue was homogenized in four volumes of buffer: $4 \mathrm{ml}$ buffer per $1 \mathrm{~g}$ tissue wet weight (A. simplex larvae in 10 volumes of buffer, $10 \mathrm{ml}$ buffer per $1 \mathrm{~g}$ tissue wet weight) and centrifuged at $10,000 \times \mathrm{g}$ for $20 \mathrm{~min}$ at $4{ }^{\circ} \mathrm{C}$. An aliquot of the supernatant (the "S9" fraction) was stored at $-80{ }^{\circ} \mathrm{C}$ and used in the assay. 
Fig. 1 Sampling sites of herring: Vistula Lagoon (black circle), Gulf of Gdansk (black square), and middle coast (black triangle)

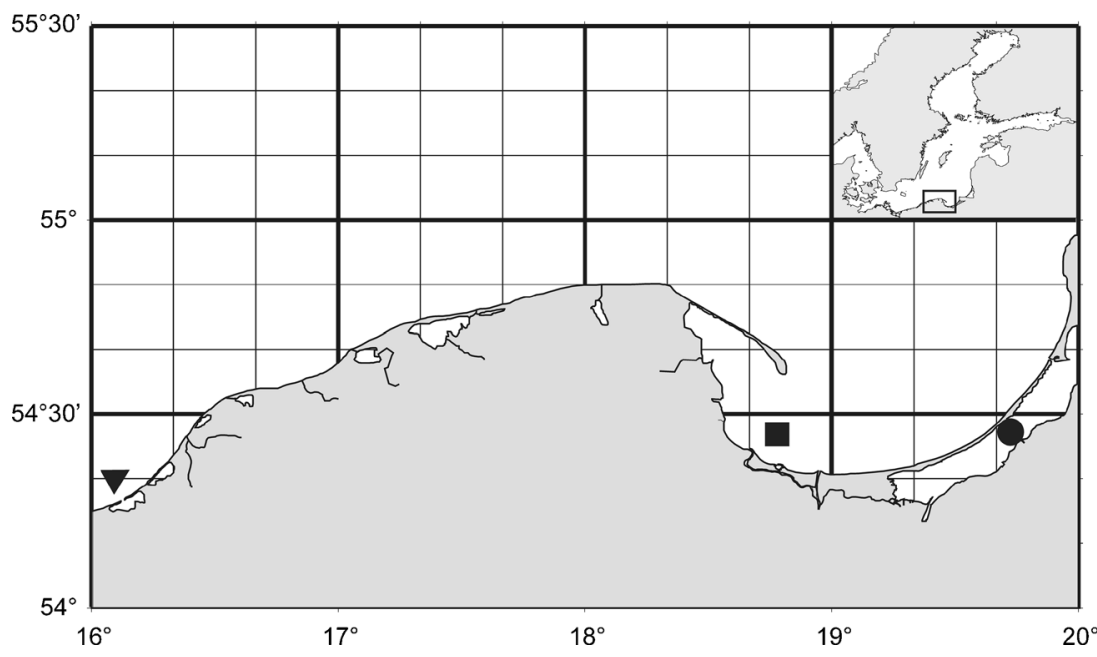

Enzyme activity determination

The AChE activity determinations in herring and parasites (extracts of post-secretory larvae and E/S products obtained from live worms) were performed using a method described by Ellman et al. (1961) and adapted for use with a microplate reader (Bocquene and Galgani 1998). The enzyme kinetics were monitored at $412 \mathrm{~nm}$ using an absorbance microplate reader (iMark, Bio-Rad) and a standard reaction mixture (final volume $0.38 \mathrm{ml}$ ) containing $0.02 \mathrm{M}$ phosphate buffer (pH 7.0), 0.01 M DTNB [5,5'-dithiobis(2-nitrobenzoic acid)] and $2.6 \mathrm{mM}$ acetylthiocholine iodide (ACTC). Protein concentration was determined as described by Bradford (1976) using the Protein Kit II (Bio-Rad) and bovine serum albumin as the protein standard.

\section{Statistical analysis}

Generalized linear models (GLMs) (McCullagh and Nelder 1989) were applied to analyze AChE activity in host and parasites with respect to the dependency on biological and spatial parameters. The following model was fitted (separately for host and parasites):

$\ln (\mathrm{AChE})=$ area + sex + gon $+\mathrm{TL}+$ error

where $\ln (\mathrm{AChE})$ represents log-transformed AChE activity of host or parasite; area, the sampling area; sex, the sex of the host; gon, the gonad developmental stage of the host; and TL, the total body length of the host. TL was taken as a covariate, whereas area, sex and gon were treated as factors. The error distribution was assumed to be normal, and the identity link function was used. Corner point parameterization was used, i.e. factor effects for level one were assumed to be zero for all factors. Thus, the factor effects for the other levels may be regarded as the difference between the effect at any given level and the effect at level one. First, the initial model (which included all variables and factors considered) was fitted. The significance of the factors and covariates was then tested, and only significant terms were left in the final model. Tests were performed by deletion, and those terms whose deletion did not result in a significant increase in deviance (i.e. the GLM measure of discrepancy between the modelled and observed values) were excluded from the model. Distributions of the model residuals were analyzed to test the model assumptions and performance.

\section{Results}

The collected material comprised 107 sets of host and parasite samples (herring muscle tissue, A. simplex post-secretory larvae and its E/S products). Results of enzyme activity measurements indicated that the AChE level was much higher in A. simplex larvae than in herring host tissue and that an inverse relationship existed between enzyme activities of the host and its parasites ("mirror effect"). In the Vistula Lagoon samples, the highest mean activity in herring (19.32 $\mathrm{nM} / \mathrm{min} / \mathrm{mg}$ protein) corresponded to the lowest mean enzyme activity in A. simplex post-secretory larvae (111.78 $\mathrm{nM} / \mathrm{min} / \mathrm{mg}$ protein) and in E/S products obtained from parasites $(47.73 \mathrm{nM} / \mathrm{min} / \mathrm{mg}$ protein). Conversely, the lowest $\mathrm{AChE}$ activity in fish tissue (11.54 $\mathrm{nM} / \mathrm{min} / \mathrm{mg}$ protein) was associated with the highest enzyme activity in post-secretory larvae $(136.26 \mathrm{nM} / \mathrm{min} / \mathrm{mg}$ protein) and its $\mathrm{E} / \mathrm{S}$ products $(64.61 \mathrm{nM} / \mathrm{min} / \mathrm{mg}$ protein; Fig. 2). On average, AChE activity was approximately fourfold higher in $\mathrm{E} / \mathrm{S}$ products and eightfold higher in post-secretory larvae than in herring muscle tissue.

Mean enzyme activity was higher in female $(15.93 \mathrm{nM} / \mathrm{min} /$ $\mathrm{mg}$ protein) than in male hosts $(14.18 \mathrm{nM} / \mathrm{min} / \mathrm{mg}$ protein), while values recorded for $A$. simplex were lower in parasites from females $(121.36 \mathrm{nM} / \mathrm{min} / \mathrm{mg}$ protein) than from males (130.74 nM/min/mg protein; Table 1). The highest enzyme activity in female herring sampled in the Vistula Lagoon 
Fig. 2 Acetylcholinesterase activity ( $\mathrm{nM} / \mathrm{min} / \mathrm{mg}$ protein; with SE) in herring muscle tissue (host), E/S products and postsecretory larvae of $A$. simplex parasites in three areas of the Baltic Sea

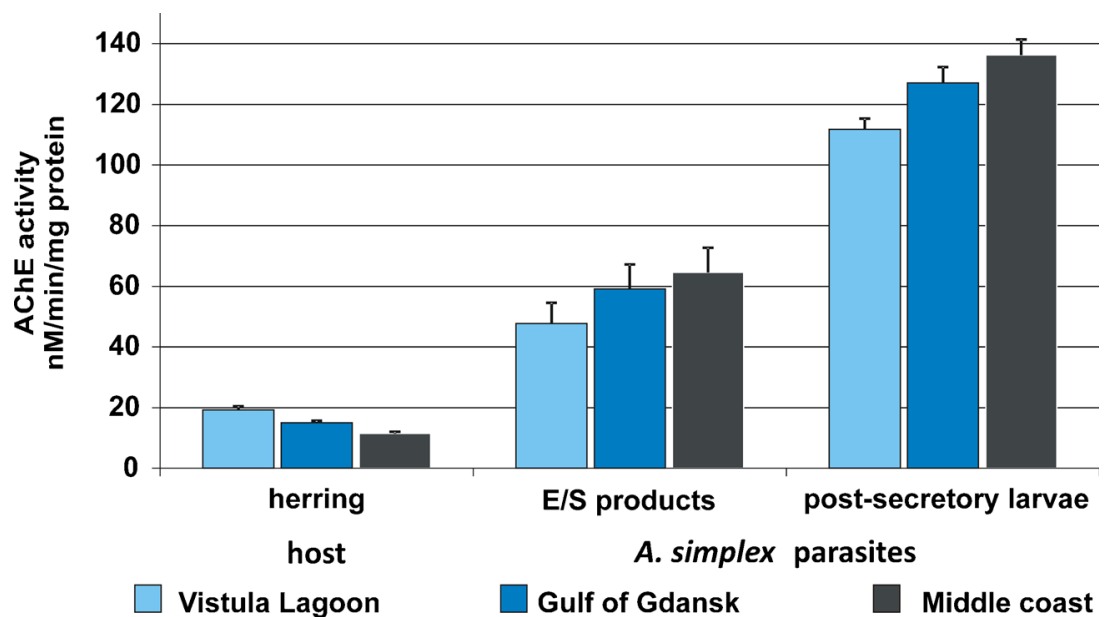

(20.70 $\mathrm{nM} / \mathrm{min} / \mathrm{mg}$ protein) was accompanied by the lowest level of $\mathrm{AChE}$ in both post-secretory A. simplex larvae (107.61 $\mathrm{nM} / \mathrm{min} / \mathrm{mg}$ protein) and its $\mathrm{E} / \mathrm{S}$ products (45.01 nM/min/mg protein; Table 1). The greatest divergence between male hosts (lowest level of $11.05 \mathrm{nM} / \mathrm{min} / \mathrm{mg}$ protein) and post-secretory larvae (highest level of $138.75 \mathrm{nM} /$ $\mathrm{min} / \mathrm{mg}$ protein) was recorded in the middle coast (Table 1).

The GLM model of AChE activity in herring muscle tissue explained $27 \%$ of the variance. The area effect was highest in the Vistula Lagoon and differed significantly from the Gulf of Gdansk $(p=0.003)$ and the middle coast $(p<0.001)$. The effect of fish sex was higher in females than in males, but the level of significance ( $p$ value) was only 0.075 . The GLM model of AChE activity in $A$. simplex post-secretory larvae revealed the opposite biomarker response in parasites: the area effect was lowest in the Vistula Lagoon compared to the Gulf of Gdansk $(p=0.014)$ and the middle coast $(p<0.001)$. The effect of the host's sex was significantly higher in parasites collected from male, as opposed to female hosts $(p=0.05)$. The model explained $13.5 \%$ of the variance. The parameter estimates for the models of AChE activity in herring and $A$. simplex larvae are provided in Table 2. The AChE activity in the hostparasite system showed an inverse relationship (mirror effect) of area and sex effects (Fig. 3a, b).

\section{Discussion}

The data presented in this study show that mean AChE activity was approximately fourfold higher in E/S products and eightfold higher in somatic extracts of post-secretory A. simplex larvae than in the muscle tissue of its host, herring. Strikingly, the AChE activity level in nematodes was inversely related to the enzyme activity in their hosts: for example, reduced AChE activity in herring was accompanied by increased enzyme activity in its parasites. The threshold of sensitivity to insecticides is usually low in marine organisms, and exposure to pesticides at concentrations of $0.1-1 \mu \mathrm{g} / \mathrm{l}$ may lead to AChE inhibition in fish (Klaverkamp and Hobden 1980; Habig et al. 1986). Enzyme activity measurements

Table 1 Acetylcholinesterase activity (nM/min/mg protein; with SE) in herring muscle tissue (host) and A. simplex parasites (E/S products and postsecretory larvae) in three areas of the Baltic Sea, in relation to the host's sex

\begin{tabular}{|c|c|c|c|c|c|c|c|c|}
\hline \multirow{3}{*}{$\begin{array}{l}\text { Host's sex } \\
\text { Males }\end{array}$} & \multirow{3}{*}{$\begin{array}{l}\text { Area } \\
\text { Vistula Lagoon }\end{array}$} & \multirow{3}{*}{$\begin{array}{l}N \\
\\
14\end{array}$} & \multirow{3}{*}{$\begin{array}{c}\text { Herring } \\
17.83\end{array}$} & \multirow[b]{3}{*}{$(1.61)$} & \multicolumn{4}{|c|}{ A. simplex } \\
\hline & & & & & \multicolumn{2}{|c|}{ E/S products } & \multicolumn{2}{|c|}{ Post-secretory larvae } \\
\hline & & & & & 50.65 & $(10.15)$ & 116.24 & $(4.62)$ \\
\hline & Gulf of Gdansk & 22 & 14.13 & $(0.92)$ & 49.16 & $(9.20)$ & 134.14 & $(7.16)$ \\
\hline & Middle coast & 16 & 11.05 & $(0.74)$ & 56.65 & $(8.91)$ & 138.75 & $(7.99)$ \\
\hline Sum & & 52 & 14.18 & $(0.71)$ & 51.87 & $(5.40)$ & 130.74 & $(4.22)$ \\
\hline \multirow[t]{3}{*}{ Females } & Vistula Lagoon & 15 & 20.70 & $(1.75)$ & 45.01 & $(9.48)$ & 107.61 & $(5.24)$ \\
\hline & Gulf of Gdansk & 21 & 16.14 & $(1.29)$ & 69.54 & $(12.31)$ & 119.60 & $(6.49)$ \\
\hline & Middle coast & 19 & 11.95 & $(0.87)$ & 71.31 & (13.09) & 134.16 & $(6.90)$ \\
\hline Sum & & 55 & 15.93 & $(0.87)$ & 63.46 & $(7.06)$ & 121.36 & $(3.92)$ \\
\hline Total Sum & & 107 & 15.08 & $(0.57)$ & 57.83 & $(4.50)$ & 125.92 & $(2.90)$ \\
\hline
\end{tabular}

$N$ number of sample sets 
Table 2 Parameter estimates (with SE) for models of $\mathrm{AChE}$ activity in herring muscle tissue (host) and A. simplex post-secretory larvae (parasites)

\begin{tabular}{llllr}
\hline & Parameter/factor & Estimate & SE & $p$ \\
\hline Herring muscle tissue (host) & Intercept & 2.85 & 0.07 & $<0.001$ \\
& Vistula Lagoon & 0 & Aliased & \\
& Gulf of Gdansk & -0.24 & 0.08 & 0.003 \\
& Middle coast & -0.51 & 0.08 & $<0.001$ \\
& Males & 0 & Aliased & \\
& Females & 0.11 & 0.06 & 0.075 \\
A. simplex post-secretory larvae (parasites) & Intercept & 4.74 & 0.04 & $<0.001$ \\
& Vistula Lagoon & 0 & Aliased & \\
& Gulf of Gdansk & 0.13 & 0.05 & 0.014 \\
& Middle coast & 0.21 & 0.05 & $<0.001$ \\
& Male hosts & 0 & Aliased & \\
& Female hosts & -0.08 & 0.04 & 0.052 \\
\hline
\end{tabular}

Variance accounted for in models: host $27 \%$ and parasites $13.5 \%$ and $\mathrm{AChE}$ inhibition in herring sampled in middle coast was also accompanied by increasing enzyme activity in E/S products of nematodes.

A. simplex larvae have a high threshold of sensitivity to carbofuran (Podolska et al. 2008): no AChE inhibition was recorded in body extracts of larvae after exposure to carbofuran concentrations of up to $500 \mu \mathrm{g} / \mathrm{l}$. Furthermore, the GLM model indicated that AChE activity was significantly elevated in larvae exposed to high concentrations of this carbamate pesticide. Recent results, obtained by native polyacrylamide gel electrophoresis of the somatic extracts and E/S products from live parasites, indicate the presence of two molecular forms of AChE in A. simplex larvae (Podolska et al. 2012). This latest study also revealed that AChE activity was higher in tissue homogenates prepared from A. simplex larvae frozen after the secretion of the enzyme than in larvae refer to enzyme activity in post-secretory $A$. simplex larvae,

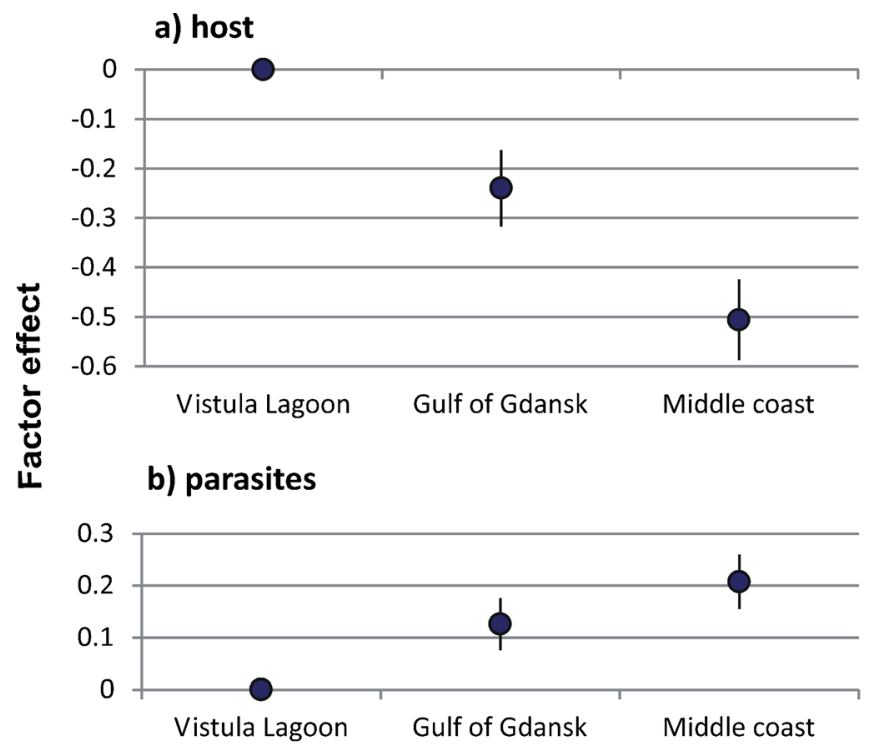

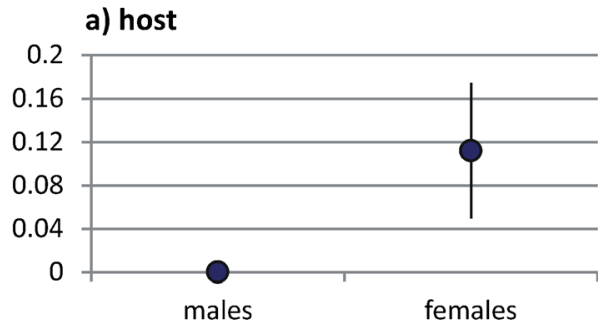

b) parasites

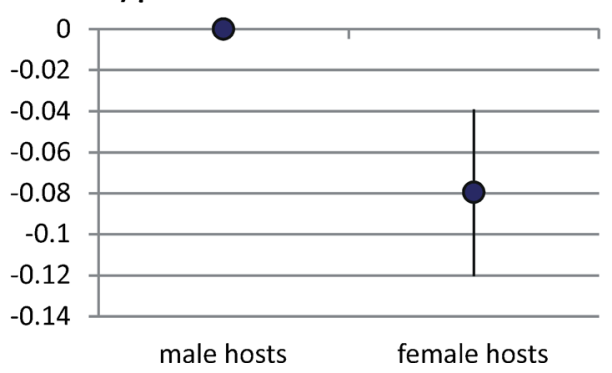

Fig. 3 Effects of sampling area and sex of the host (with SE) estimated for models of AChE activity in herring muscle tissue (host) and A. simplex postsecretory larvae (parasites) 
frozen immediately after collection; moreover, $\mathrm{AChE}$ in the $\mathrm{E} / \mathrm{S}$ products of live parasites was characterized by a high level of activity. The results suggest that $A$. simplex larvae may have developed a mechanism of resistance to neurotoxic agents.

In many species of invertebrates, these resistance mechanisms are directly related to the activity of AChE. Chang and Opperman (1991) showed that class C AChEs from root-knot nematodes of the genus Meloidogyne are highly resistant to OPs and CBs. Kang et al. (2011b) proposed that soluble AChE plays an important role in the chemical defence system of B. xylophilus against various xenobiotics. Mutations in the $\mathrm{AChE}$ gene, responsible for AChE insensitivity to insecticides, have been identified in several species of arthropods, i.e. Musca domestica (Kozaki et al. 2001; Walsh et al. 2001), Drosophila melanogaster (Charpentier and Fournier 2001; Fournier 2005) and mosquitoes (Perera et al. 2008). Resistance to insecticides may also be enhanced by overproduction of AChE (Fournier et al. 1992; Charpentier and Fournier 2001). Thus, the high threshold of sensitivity to carbofuran in A. simplex larvae may be attributable either to a form of AChE that is resistant to inhibitors or to overexpression of the enzyme. A third possible adaptive mechanism, however, might be the secretion of AChE by these nematodes in response to adverse environmental conditions. In this model, secreted AChE acts as a decoy molecule, which binds inhibitors and thereby reduces the exposure of neuromuscular $\mathrm{AChE}$ to neurotoxic agents.

Secreted AChEs perform functions that are nonoverlapping with those expressed in the nematode neuromuscular system (Selkirk et al. 2005a) and are important in hostparasite interactions in many nematode species. Numerous roles for this form of the enzyme have been suggested, i.e. the modulation of intestinal peristalsis (Lee 1970) and the immune response of the host (Pritchard 1995), and even protection against enzyme inhibitors present in the host's diet, which may lead to expulsion of the parasites by muscular contractions of the host (Selkirk et al. 2005b). An inverse relationship between enzyme activities in the host-parasite system is consistent with the hypothesis that these parasites enhance AChE secretion under the influence of neurotoxic compounds.

Alternatively, AChE secretion by parasites might not relate directly to anticholinergic poisoning, but instead be an indirect response to the effect of AChE inhibition in their host. Yet, another possibility is that $A$. simplex larvae produce a large amount of AChE to prevent the accumulation of host acetylcholine in the vicinity of the parasite. Bhattacharya et al. (1997) proposed that Wuchereria bancrofti microfilariae secrete AChE into the circulation to degrade host acetylcholine (ACh). Since ACh stimulates the release of lysosomal enzymes and phagocytosis, the immune response of the host is suppressed during infection. Accordingly, Hussein et al. (1999b) suggested that AChE secretion by nematode parasites should inhibit host secretory responses.

The relationship between the sex of the host and nematode AChE activity is difficult to explain. AChE activity levels were significantly higher in $A$. simplex larval extracts obtained from male, as opposed to female, herring (Podolska and Napierska 2006; Podolska et al. 2008). Similarly, sexdependent differences in mean $\mathrm{AChE}$ activities were also reported for both post-secretory larvae and their E/S products (Podolska et al. 2012). The results presented in the current report are in accordance with earlier findings. The greatest divergence was recorded between AChE activity in male herring (lowest level) and post-secretory larvae (highest level): in this, the most extreme case, the enzyme activity was over 12 times higher in parasites than in their hosts. In addition, the effect of sex was significant in both GLM models (for herring and A. simplex) and shows an inverse relationship between host and parasite AChE activities. How the sex of the host influences AChE activity in its parasites is unclear, however, although we might speculate that host sex steroid hormones affect nematode $\mathrm{AChE}$ activity and/or the rate of enzyme secretion. On the other hand, it is possible that the sex of the host indirectly influences on the response of larvae; thus, AChE secretion may be induced by the low level of enzyme activity in male hosts.

In summary, AChE secretion by A. simplex may constitute an adaptive mechanism that promotes survival under adverse environmental conditions. Larvae probably increase secretion of this enzyme in response to a direct and/or indirect effect of neurotoxic compounds. This is the first report of such a phenomenon in A. simplex.

Open Access This article is distributed under the terms of the Creative Commons Attribution License which permits any use, distribution, and reproduction in any medium, provided the original author(s) and the source are credited.

\section{References}

Arpagaus M, Richier P, Berge JB, Toutant JP (1992) Acetylcholinesterases of the nematode Steinernema carpocapsae. Characterization of two types of amphiphilic forms differing in their mode of membrane association. Eur J Biochem 207:1101-1108

Barsiene J, Lehtonen KK, Koehler A, Broeg K, Vuorinen PJ, Lang T, Pempkowiak J, Syvokiene J, Dedonyte V, Rybakovas A, Repecka R, Vuontisjarvi H, Kopecka J (2006) Biomarker responses in flounder (Platichthys flesus) and mussel (Mytilus edulis) in the KlaipedaButinge area (Baltic Sea). Mar Pollut Bull 53:422-436

Baxter GD, Barker SC (2002) Analysis of the sequence and expression of a second putative acetylcholinesterase cDNA from organophosphatesusceptible and organophosphate-resistant cattle ticks. Insect Biochem Mol Biol 32:815-820

Bhattacharya C, Singh RN, Misra S, Rathaur S (1997) Diethylcarbamazine: effect on lysosomal enzymes and acetylcholine in Wuchereria bancrofti infection. Trop Med Int Health 2:686-690 
Bocquene G, Galgani F (1998) Biological effects of contaminants: cholinesterase inhibition by organophosphate and carbamate compounds. ICES Techniques in Marine Environmental Sciences No.22, pp 1-12

Bradford M (1976) A rapid and sensitive method for the quantitation of microgram quantities of protein utilizing the principle of protein-dye binding. Anal Biochem 72:248-254

Busby DG, White LM, Pearce PA, Mineau P (1989) Fenitrothion effects on forest song-birds: a critical new look. In: Ernst WR (ed) Environmental effects of fenitrothion use in forestry. Environment Canada, Nova Scotia, pp 43-108

Chang S, Opperman CH (1991) Characterization of acetylcholinesterase molecular forms of the root-knot nematode, Meloidogyne. Mol Biochem Parasitol 49:205-214

Chang S, Opperman CH (1992) Separation and characterization of Heterodera glycines acetylcholinesterase molecular forms. J Nematol 24:148-155

Charpentier A, Fournier D (2001) Levels of total acetylcholinesterase in Drosophila melanogaster in relation to insecticide resistance. Pesticide Biochem Physiol 70(2):100-107

Combes D, Fedon Y, Grauso M, Toutant JP, Arpagaus M (2000) Four genes encode acetylcholinesterases in the nematodes Caenorhabditis elegans and Caenorhabditis briggsae. cDNA sequences, genomic structures, mutations and in vivo expression. J Mol Biol 300:727-742

Dembele K, Haubruge E, Gaspar C (1999) Recovery of acetylcholinesterase activity in the common carp (Cyprinus carpio L.) after inhibition by organophosphate and carbamate compounds. Bull Environ Contam Toxicol 62:731-742

DeVos T, Dick TA (1992) Characterization of cholinesterases from the parasitic nematode Trichinella spiralis. Comp Biochem Physiol C Comp Pharmacol 103(1):129-134

Dizer H, da Silva de Assis HC, Hansen P-D (2001) Cholinesterase activity as a bioindi-cator for monitoring marine pollution in the Baltic sea and the Mediterranean sea. In: Garrigues P, Barth H, Walker $\mathrm{CH}$, Narbonne JF (eds) Biomarkers in marine organisms: a practical approach. Elsevier, Amsterdam, p 491

Ellman GL, Courtney K, Andrres V, Featherstone RM (1961) A new and rapid colorimetric determination of acetylcholinesterase activity. Biochem Pharmacol 7:88-95

Fournier D (2005) Mutations of acetylcholinesterase which confer insecticide resistance in insect populations. Chem Biol Interact 157(158): 257-261

Fournier D, Bride JM, Hoffmann F, Karch F (1992) Acetylcholinesterase two types of modifications confer resistance to insecticide. J Biol Chem 267:14270-14274

Fulton MH, Key PB (2001) Acetylcholinesterase inhibition in estuarine fish and invertebrates as an indicator of organophosphorus insecticide exposure and effects. Environ Toxicol Chem 20(1):37-45

Griffiths G, Pritchard DI (1994) Purification and biochemical characterisation of acetylcholinesterase (AChE) from the excretory/secretory products of Trichostrongylus colubriformis. Parasitology 108:579-586

Grigg ME, Tang L, Hussein AS, Selkirk ME (1997) Purification and properties of monomeric (G1) forms of acetylcholinesterase secreted by Nippostrongylus brasiliensis. Mol Biochem Parasitol 90:513-524

Habig C, Di Guilio RT, Nomeir AA, Abou Donia AMB (1986) Comparative toxicity, cholinergic effects and tissue levels of S, S, S-tri-n-butyl phosphorotrithioate (DEF) to channel catfish (Ictalurus punctatus) and blue crab (Callinectes sapidus). Aquat Toxicol 9(4 5):193-206

Hussein AS, Grigg ME, Selkirk ME (1999a) Nippostrongylus brasiliensis: characterisation of a somatic amphiphilic acetylcholinesterase with properties distinct from the secreted enzymes. Exp Parasitol 91:144-150

Hussein AS, Chaco NMR, Smith AM, Tosado-Acevedo R, Selkirk ME (1999b) Cloning, expression, and properties of a nonneuronal secreted acetylcholinesterase from the parasitic nematode Nippostrongylus brasiliensis. J Biol Chem 274:9312-9319
Hyne RV, Maher WA (2003) Invertebrate biomarkers: links to toxicosis that predict population decline. Ecotoxicol Environ Saf 54(3):366374

Kang JS, Lee DW, Choia JY, Je YH, Koh YH, Lee SH (2011a) Three acetylcholinesterases of the pinewood nematode, Bursaphelenchus xylophilus: insights into distinct physiological functions. Mol Biochem Parasitol 175:154-161

Kang JS, Lee DW, Koh YH, Lee SH (2011b) A soluble acetylcholinesterase provides chemical defense against xenobiotics in the pinewood nematode. PLoS ONE 6(4):e19063. doi:10.1371/journal. pone. 0019063

Klaverkamp JF, Hobden BR (1980) Brain acetylcholinesterase inhibition and hepatic activation of acephate and fenitrothion in rainbow trout (Salmo gairdneri). Can J Fish Aquat Sci 37(9):1450-1453. doi:10. 1139/f80-186

Kozaki T, Shono T, Tomita T, Kono Y (2001) Fenitroxon insensitive acetylcholinesterases of the housefly Musca domestica associated with point mutations. Insect Biochem Mol Biol 31:991-997

Lazari O, Hussein AS, Selkirk ME, Davidson AJ, Thompson FJ, Matthews JB (2003) Cloning and expression of two secretory acetylcholinesterases from the bovine lungworm, Dictyocaulus viviparus. Mol Biochem Parasitol 132:83-92

Lazari O, Selkirk ME, Ploeger HW, Matthews JB (2004) A putative neuromuscular acetylcholinesterase gene from Dictyocaulus viviparus. Mol Biochem Parasitol 136:313-317

Lee DL (1970) The fine structure of the excretory system in adult Nippostrongylus brasiliensis (Nematoda) and a suggested function for the "excretory glands". Tissue Cell 2:225-231

Lee D-W, Kim S-S, Shin SW, Kim WT, Boo KS (2006) Molecular characterization of two acetylcholinesterase genes from the oriental tobacco budworm, Helicoverpa assulta (Guenee). Biochim Biophys Acta 1760:125-133

Massoulie J (2002) The origin of the molecular diversity and functional anchoring of cholinesterases. Neurosignals 11:130-143

McCullagh P, Nelder JA (1989) Generalized linear models, 2nd edn. Chapman and Hall/CRC, London, p 532

Morales J, Manso JA, Cid A, Lodeiro C, Mejuto JC (2012) Degradation of carbofuran derivatives in restricted water environments: basic hydrolysis in AOT-based microemulsions. J Colloid Interface Sci 372:113-120

Napierska D, Podolska M (2005) Biomarkers of contaminant exposure: results of a field study with flounder (Platichthys flesus) from the southern Baltic Sea. Mar Pollut Bull 50:758-767

Niemi H, Jonsson H, Schneider R, Schiedek D (2002) Muscular AChE and hepatic EROD as biomarkers of exposure in male Baltic cod (Gadus morhua). Mar Environ Res 54(3-5):841-842. In: Marine Environmental Research. Applied Science Publishers, Essex, ISSN 0141-1136

Perera MDB, Hemingway J, Karunaratne SP (2008) Multiple insecticide resistance mechanisms involving metabolic changes and insensitive target sites selected in anopheline vectors of malaria in Sri Lanka. Malar J 7:168

Pezzementi L, Krejci E, Chatonnet A, Selkirk ME, Matthews JB (2012) A tetrameric acetylcholinesterase from the parasitic nematode Dictyocaulus viviparus associates with the vertebrate tail proteins PRiMA and ColQ. Mol Biochem Parasitol 181:40-48

Podolska M, Napierska D (2006) Acetylcholinesterase activity in hosts (herring Clupea harengus) and parasites (Anisakis simplex larvae) from the southern Baltic. ICES J Mar Sci 63(1):161-168. doi:10. 1016/j.icesjms.2005.08.001

Podolska M, Mulkiewicz E, Napierska D (2008) The impact of carbofuran on acetylcholinesterase activity in Anisakis simplex larvae from Baltic herring. Pestic Biochem Physiol 91(2):104-109. doi: 10.1016/j.pestbp.2008.01.008 doi:10.1016/j.pestbp.2008.01. 008\#doilink 
Podolska M, Nadolna K, Wąs A, Gosz E, Szostakowska B (2012) Acetylcholinesterase secretion by third-stage larvae of Anisakis simplex (Nematoda: Anisakidae) from Baltic herring. Bull Eur Assoc Fish Pathol 32(6):225-232

Pritchard D (1995) The survival strategies of hookworms. Parasitol Today 11(7):255-259. doi: 10.1016/0169-4758(95)80206-1 DOI:10.1016/ 0169-4758\%2895\%2980206-1\#doilink

Pritchard DI, Brown A, Toutant J-P (1994) The molecular forms of acetylcholinesterase from Necator americanus (Nematoda), a hookworm parasite of the human intestine. Eur J Biochem 219:317-323

Sanderson BE (1972) Release of cholinesterase by adult Nippostrongylus brasiliensis in vitro. Z Parasitenkunde 40(1):1-7

Selkirk ME, Lazari O, Hussein AS, Matthews JB (2005a) Nematode acetylcholinesterases are encoded by multiple genes and perform non-overlapping functions. Chem Biol Interact 157-158:263-268

Selkirk ME, Lazari O, Matthews JB (2005b) Functional genomics of nematode acetylcholinesterases. Parasitology 131:S3-S18

Sharma S, Misra S, Rathaur S (1998) Secretory acetylcholinesterase of Setaria cervi microfilariae and its antigenic cross reactivity with Wuchereria bancrofti. Trop Med Int Health 3:46-51
Talesa V, Romani R, Grauso M, Rosi G, Giovannini E (1997) Expression of a single dimeric membrane-bound acetylcholinesterase in Parascaris equorum. Parasitology 115:653-660

Toutant JP (1989) Insect acetylcholinesterase: catalytic properties, tissue distribution and molecular forms. Prog Neurobiol 32:423-446

Walsh SB, Dolden TA, Moores GD, Kristensen M, Lewis T, Devonshire AL, Williamson MS (2001) Identification and characterization of mutations in housefly (Musca domestica) acetylcholinesterase involved in insecticide resistance. Biochem J 359:175-181

Weill M, Fort P, Berthomieu A, Dubois MP, Pasteur N, Raymond M (2002) A novel acetylcholinesterase gene in mosquitoes codes for the insecticide target and is non-homologous to the ace gene in Drosophila. Proc R Soc Lond B 269:2007-2016

Weill M, Lutfalla G, Mogensen K, Chandre F, Berthomieu A, Berticat C, Pasteur N, Philips A, Fort P, Raymond M (2003) Comparative genomics: insecticide resistance in mosquito vectors. Nature 423:136-137

Zinkl JG, Shea PJ, Nakamoto RJ, Callman J (1987) Technical and biological considerations for the analysis of brain cholinesterase of rainbow trout. Trans Am Fish Soc 116(4):570-573. doi:10.1577/ 1548-8659(1987)116<570:TABCFT>2.0.CO;2 